\title{
Intangible Assets and Goodwill Valuation in the European Union
}

\author{
Vladimír Kulil \\ Technical University of Ostrava, Faculty of Economics, Appraisal Institut, Czech Republic
}

\begin{abstract}
European valuation standards TEGoVA have conception for valuation of intangible assets and they formed to conform to International valuation standards (IVS) also to reach worldwide consensus in best practices in valuation process. The process of valuation of intangible influences was also surveyed in China, Hong Kong, USA, Canada, Japan, Germany, UK, Poland, Russia and overall in the Europe. Situation in mentioned locations is similar, valuation of intangible influences has not been determined by a concrete list of items and there has not been established concrete clear process. The subject matter of this paper is a proposal for a method of valuation of intangible effects that will impact assets prices. It deals with proposed procedures for valuation of intangible assets. Special effects are in particular name, historical value, design, quality of layout, security aspects, accessibility, and conflict groups of inhabitants in or near the property, location, provenience and other.
\end{abstract}

Keywords: European integration, Market value, Tangible assets, Intangible assets, Goodwill

\section{Introduction}

Valuation of intangible assets in the European Union include certain specifics compared to cost assets (Brachmann 1993, Eurostat 1998-2016). The specifics should be considered in the methodology and in final price (Seabrooke, Kent, Hwee 2004). There exists a basic consensus in the way of tangible assets evaluation, in the case of intangible assets there is not. Aim is to introduce the scientific public with a different view on the essence of valuation (Shetty 1995). New software is designed for asset valuation using the methods of cost, yield and comparative value with the special feature that allows the division of assets, including real estate on tangible and intangible parts. The software calculates enter information separately goodwill or badwill (Kulil 2015).

\section{Problem Formulation and Methodology}

Goodwill is in the European Union an economic term denoting the difference between the market value of the company and sub-stance price, less any liabilities. Indicates a value, intangible assets such as customer relationships, reputation (Horne 1989). Reflects market position, quality and especially tradition. Goodwill can distinguish two ways, on the goodwill of the original and secondary. Initial goodwill to create their own company's business activities, but not in the accounts of a company recognized because it is not reliably measurable (Čsú Praha 1993-2016). Secondary acquires goodwill on the acquisition of another company. Badwill is negative goodwill.

\subsection{Model and Data}

Software can use appraisers and forensic experts in the field of economics, valuation, which the program will be free to download. The software is available on the website of the Institute of Electronic Appraisal of the Faculty of Economics at the Technical University of Ostrava, http://www.ekf.vsb.cz/k166/cs/ (Kulil 2015). See Figure 1 for details. 


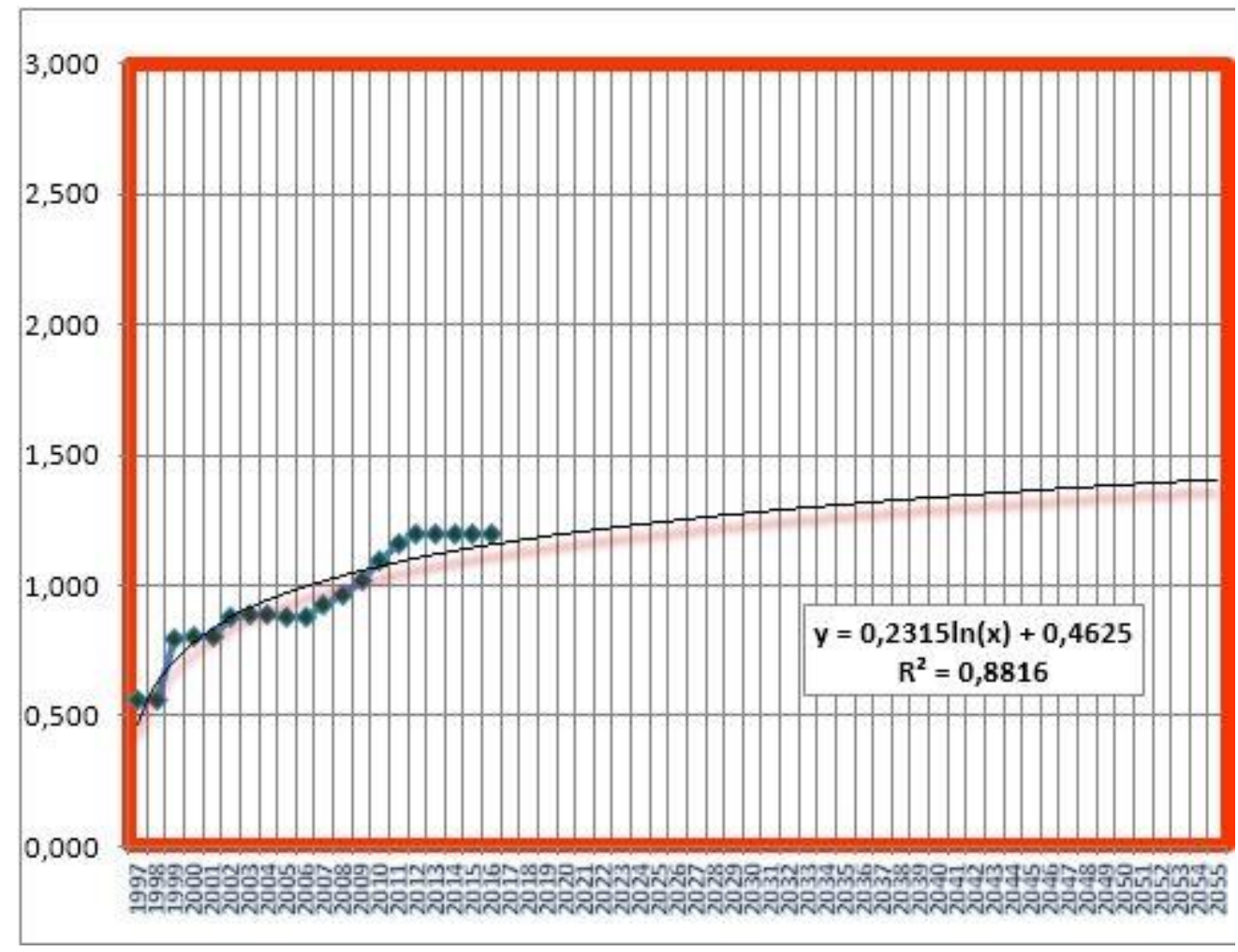

Figure 1: Development of marketability in period 1997 - 2016 (example of coefficients of marketability $\mathrm{kp}$ )

Source: marketability coefficients according to records of the ministry of finance of the czech republics

Here we see the automatically generated price perspective of the asset for the future at annual intervals up to 2055, when the market value of this example is estimated at the selling rate (coefficient of marketability) of 1.40 against the cost-determined price - price of substance.

\section{Problem Solution}

Following procedure for valuation of goodwill and badwill type of assets of enterprises resulting from mentioned model approaches appears as the most objective. Enterprise assets will be evaluated by comparative, yield and cost method. The price will be adjusted in each used method according to an influence of special effects, which means good or bad reputation and according to other special effects which influence usual market price. Other evaluated intangible assets of an enterprise (except goodwill) are included in the price if they really exist

\subsection{The Cost Value of Estate Valuation in the European Union}

In order to calculate the current value of listed historical buildings the author recommends to count significantly higher lifespan than in the case of unprotected buildings. Other proposed life span would probably not normally be less than the age of the main volumes of construction.

- The cost of major structures - indicating processor (price regulation, budget, historic price index and other).

- Cost value of other buildings, technologies and landscaping - will insert.

- The cost of permanent growth - indicating processor.

- The price of land price map or a comparison of average quality - indicating processor.

- Current price structures in total will be calculated automatically.

- Cost value of land and vegetation in total will be calculated automatically. 
- Coefficient of marketability Kp (KP) state statistical processor based on the price determined by the current price regulation or like estimate. For detail also see table no. 1

- Graf history years 1997 - 2016 and give the processor price by historical data or according to valuator data estimate. For subsequent years, according to statistical data indicate Čsú, Eurostat, US data.

- The development trend for the next 40 years the program generates automatically based on the logarithmic regression curve. See Figure 1 for details.

Table 1: List of groups and items of special intangible effects

\begin{tabular}{|c|c|c|}
\hline Nr. & $\begin{array}{l}\text { Intangible pricing influences by modifying } K_{p} \text { per item with } \\
\text { detailed list itemization }\end{array}$ & $\begin{array}{l}\text { Recommende } \\
\text { d range } \%\end{array}$ \\
\hline 1. & $\begin{array}{l}\text { Location favorableness in the locality compared to the } \\
\text { average of the locality }\end{array}$ & $\begin{array}{l}\text { From }-10 \% \\
\text { to }+10 \%\end{array}$ \\
\hline 2. & Estate name, prestigiosness, dominance & $\begin{array}{l}\text { From }-10 \% \\
\text { to }+10 \%\end{array}$ \\
\hline 3. & Historical value, cost of preservation of monuments & $\begin{array}{l}\text { From }-10 \% \\
\text { to }+10 \%\end{array}$ \\
\hline 4. & Architectonic rendering, the quality of disposition, view & $\begin{array}{l}\text { From }-10 \% \\
\text { to }+10 \%\end{array}$ \\
\hline 5. & $\begin{array}{l}\text { Safety, users' privacy, conflict inhabitants in the } \\
\text { surroundings }\end{array}$ & $\begin{array}{l}\text { From }-70 \% \\
\text { to }+10 \%\end{array}$ \\
\hline 6. & $\begin{array}{l}\text { Danger of floods, landslides, damage from transport, bad } \\
\text { smells, air pollution }\end{array}$ & $\begin{array}{l}\text { From }-10 \% \\
\text { to }+10 \%\end{array}$ \\
\hline 7. & Dangerous disposition and harmful material, radon & $\begin{array}{l}\text { From }-10 \% \\
\text { to } 0 \%\end{array}$ \\
\hline 8. & $\begin{array}{l}\text { Transport accessibility with respect to the average standard } \\
\text { in the surroundings }\end{array}$ & $\begin{array}{l}\text { From }-10 \% \\
\text { to }+10 \%\end{array}$ \\
\hline 9. & $\begin{array}{l}\text { Impact of terraced housing, a building inside a row or at its } \\
\text { end }\end{array}$ & $\begin{array}{l}\text { From }-10 \% \\
\text { to } 0 \%\end{array}$ \\
\hline 10. & Pricing perspective of estate and other influences & $\begin{array}{l}\text { From }-70 \% \\
\text { to }+10 \%\end{array}$ \\
\hline
\end{tabular}

\section{Source: Author's calculations}

The processor in the European Union will complement estimation of the percentage, and only if different from the current market situation. Span adjustment is recommended. Total intangible special effects with real estate above the threshold [\%] are calculated automatically, including cost price, including land and vegetation to intangible property (Kulil 2014).

\subsection{Yield Valuation}

Long historical period of market economy showed that the property purchase in order to ensure a reasonable profit (under the condition of proper management) is worth. This means that the yield value should theoretically be in the performing companies and real estate standardly higher than the cost price (after redundant assets deduction). In practice, cost value is often higher, 


\section{Vladimír Kulil \\ Intangible Assets and Goodwill Valuation in the European Union}

because there is usually a large surplus of production resources and real estate, they are in an inefficient structure and there may be a negative intangibles (badwill).

- Option is set to eternal annuity; the process can be changed for different ways of calculating the yield value.

- Complete up net annual revenue of buildings, including land and forests, assets.

- The rate of capitalization for standard conventional property - indicate the processor.

- The rate for capitalization of intangible property, including the effects will be calculated automatically as a deduction from recalculation or capitalization rates mentioned in the previous item by the coefficient sales centesimal degree - as an expression of risk premiums or deductions.

- Yield value: Net income / capitalization rate [\%] - calculates automatically.

\subsection{Comparative Valuation}

The comparative value should be determined as the median of Gaussian curve of statistical evaluation of individual prices which are compared. For the calculation of the comparative value it is necessary to consider the fact that every property is different, there are always differences and exactly the same comparative representatives cannot be found. Therefore, the comparative value is only one of the several methods - the pillars for the determination of market prices.

- Comparison value separately calculates and give the property a normal average numerical value.

- Comparison value, including intangible effects of excess is calculated automatically by the coefficient of marketability of the cost method.

\subsection{The Market Value of Property}

In the European Union is calculated automatically as the weighted average cost, revenue, and by comparison, the ratio in the formula determines the processor. It can be added to the formula, the value of 0.0 to reset some of the methods of valuation. Since the market price should be deducted from the value of easements.

\subsection{Price of Goodwill}

Goodwill or badwill as a summary of specific intangible impacts on the market price is calculated as the difference between the market value of the property and its cost price. This rule applies generally to movable property, immovable property and businesses. Plots of land price is represented by all rights related to human activities on a land including construction and construction rights. Plot of land is to full extend intangible asset only of goodwill type.

- Coefficient of intangible assets (KP) is the share price of market value and the prices of cost value.

- When the value KP is greater than 1.00 with, a total is goodwill.

- At values less than $1.00 \mathrm{KP}$, a total is badwill.

- Estimated price perspective - complete processor awards: stagnation (moderate or fast) decline, growth.

\section{New Findings and Special Influences Valuation}

Following procedure for valuation of goodwill and badwill type of assets of enterprises resulting from mentioned model approaches appears as the most objective. The amount of goodwill (GW) or badwill $(B W)$, is the difference market price $(C O)$ and cost price $(C C)$ as:

$$
\mathrm{GW}(\mathrm{BW})=\mathrm{CO}-\mathrm{CC} \text {. }
$$

The market value $C O$ is determined by multiplying the cost value $C C$ (replacement cost less depreciation, or material value) by marketability coefficient $K P$ according to the relationship

$$
\mathrm{CO}=\mathrm{CC} \times \mathrm{KP} \text {, }
$$

it follows that

$$
\mathrm{KP}=\mathrm{CO} / \mathrm{CC} \text {. }
$$




\section{Vladimír Kulil \\ Intangible Assets and Goodwill Valuation in the European Union}

The marketability coefficient is defined as the ratio between the average actual sales values achieved and the average cost prices of a comparable type of things at the particular time and location.

\subsection{Market Value CO}

According to cost, yield and comparative valuation mentioned in previous parts there will be realized an appraisal of market value (International Valuation Standards Committee 2017, Czech Act on Property Valuation No. 151/1997 Coll.). The amount of price of special influences - goodwill and badwill - will be the difference between market value of property and cost price without $K P$ (cost price $C C$ ). Amount of harm in connection with the easement will be counted as standard yield method and subtracted from the market value of the property. The maximum discount is not determined. The net income may refer to an optimistic economic situation and the possibility of smooth application of the income valuation framework (Růžičková 2013).

\subsection{Coefficient of an Intangible Asset}

We have the concept of marketability coefficient $K P$ or $K p$, in German-speaking countries a similar term market hopefulness is used (Ross, Brachmann, Holzner 1993). Its fundamental as an index for determining the degree of special influences - intangible assets (NM) in a positive or negative amount towards the current price $(C C)$ and usual market price - value of assets (CO) as a whole is not obvious.

$$
\mathrm{CO}=\mathrm{CC}+\mathrm{NM} \text {. }
$$

Coefficient of an intangible asset $\left(K_{N M}\right)$ appears to be more accurate term. An intangible character of valued property results from the mentioned term. And it shall not be determined as the estimated generally not well understood constant, which an expert established. This coefficient can be expressed by the following formula:

For real estate

$$
\mathrm{KNM}=(\mathrm{CC}+\mathrm{NM}) / \mathrm{CC} .
$$

For movables

$$
\mathrm{KNM}=(\mathrm{CC}+\mathrm{NM}) / \mathrm{CC} .
$$

For enterprises from the material substance $(S)$

$$
\mathrm{KNM}=(\mathrm{S}+\mathrm{NM}) / \mathrm{S} .
$$

\subsection{New Methodology}

Separate system of valuation tangible and intangible assets for the European Union was worked out (European Valuation Standards 2016). For the field of special influences there were proposed and defined apposite terms goodwill and badwill for valuation analogically according to the terms used by economists and appraisal experts while appraising enterprises (Kulil 2015). Character and fundamental of marketability coefficients KP are clarified from the point of view of their relationship to tangible and intangible assets. Ten main areas and hundred items of intangible influences affecting estate price are complexly defined. The use of a unit of valuation capacity provides a signal of the quality of an asset (Fishman, Parker 2015).

Author created a software NEMO-RATUS 2017 for practical use in the European Union. Proposed procedures in the whole extend of valuation including table analysis of proposed special influences for estate with logarithmic regression and including intangible assets into cost, yield, comparative and market price are applied in the computer system.

Market price of property is automatically divided into tangible and intangible part. This is basic duality (Kumar 2018). For more details see http://www.ekf.vsb.cz/k166/cs/. Proposed procedures and detailed listing of special influences represent a comprehensive, practical and unequivocal support for the valuation practice of experts.

\section{Conclusion}

Aim of the paper was to work out a proposal for valuation of special influences in the European Union, that have an impact on estate price. Controllable procedures for the valuation of 


\section{Vladimír Kulil \\ Intangible Assets and Goodwill Valuation in the European Union}

intangible assets were proposed. System of valua-tion with direct implementation in cost, yield and comparative methods from which we can estimate the market value was proposed. In case of estate special influences are defined mostly as good or bad name of locality real estate, historical value, design, quality of layout, safety aspects, transport accessibility, conflict inhabitants in the surroundings, influence of terraced house, other influences and price perspective. Terms goodwill (GW) in case of positive impact and badwill (BW) in case of negative impact were defined for each surveyed special influence.

Proposed methodology negative is subjective approach of an expert while valuating intangible assets, each expert can work out valuation with a different result. It is not possible to avoid expert's personal view. Disproportion among individual experts valuating by market price will appear also in the future. These differences can only be reduced by accepting unified methodology such as proposed in this monograph. Future research will therefore focus on the clarification of procedures and a detailed validation of recommended tariffs for fixed assets.

\section{References}

- Brachmann R. (1993), Construction costs of industrial buildings, commercial factory price of Real Estate, insurance rates. Praha, Czech Republic: CONSULTINVEST.

- Horne V. J. (1989), Financial Management and Policy. New Jersey, USA: Englewood Cliffs.

- Kulil V. (2014), Goodwill and Valuation. Brno, Czech Republic: AN CERM s.r.o.

- Kulil V. (2015), Goodwill and Valuation. Saarbrücken, Germany: OmniScriptum GmbH \& Co. KG.

- Ross-Brachmann-Holzner, (1993). Detection of construction of the buildings and commercial Real Estate values. Praha, Czech Republic: CONSULTINVEST.

- Seabrooke W., Kent P., Hwee H. (2004), International Real Estate an Institutional Approach. UK, USA, Australia: Blackwell Publishing Ltd. Crossref

- Shetty A. (1995), Finance and Integrated Gglobal Approach. USA: Austen Press, Homewood.

- EVS - European Valuation Standards, 8. Edition 2016.

- IVS - International Valuation Standards Committee: International Valuation Standards, Edition 2017, IVSC, London, UK, 2017.

- Czech Act on Property Valuation No. 151/1997 Coll. with implementing decrees.

- Čsú (1993-2016). Statistics [online]. [cit.2016-01-02]. Available at: https://www.czso.cz/csu/czso/domov.

- EUROSTAT (1998-2016). Statistics [online]. [cit.2016-01-02]. Available at: http://ec.europa.eu/eurostat.

- Kulil V. (2015), Software for goodwill valuation VALUE-RATUS [online]. [cit.2018-02-20]. Available at: http://www.ekf.vsb.cz/k166/cs/.

- Kumar V. (2018), A Theory of Customer Valuation: Concepts, Metrics, Strategy and Implementation. Journal of Marketing Vol. 82 (January 2018), 1-19. Crossref

- Fishman M. J., Parker J. A. (2015), Valuation, Adverse Selection, and Market Collapses. Oxford University Press on behalf of The Society for Financial Studies, Advance Access publication April 9, 2015. Crossref

- Růžičková K. Application of income valuation methods: Value spread vs. net income (2013) ER-CEREI, Volume 16: 239-244 (2013). Crossref 